\title{
The Surface Layer of Mycoplasma mobile 163K and Its Possible Relevance to Cell Cohesion and Group Motility
}

\author{
By R. ROSENGARTEN, ${ }^{1}$ H. KIRCHHOFF, ${ }^{1 *}$ G. KERLEN ${ }^{2}$ \\ AND K.-H.SEACK ${ }^{2}$ \\ ${ }^{1}$ Institut für Mikrobiologie und Tierseuchen, Tierärztliche Hochschule Hannover, \\ Bischofsholer Damm 15, D-3000 Hannover 1, FRG \\ ${ }^{2}$ Institut für den Wissenschaftlichen Film, Nonnenstieg 72, D-3400 Göttingen, FRG
}

(Received 18 June 1987; revised 3 September 1987)

\begin{abstract}
Mycoplasma mobile strain 163K tends to move in multicellular configurations, either as pairs or small groups of three or more cells, or as chain-like aggregations or microcolonies. Such wandering groups arise by transient association of independently moving cells. This behaviour of $M$. mobile was microscopically investigated and documented by sequences of microcinematographic pictures, as well as by photomicrographically recorded motility tracks. The presence of an extracellular slime layer was demonstrated in thin sections, by negative staining and by scanning electron microscopy. The possible association of this layer with the cohesive properties of the mycoplasma cells, enabling the formation of wandering groups, is discussed and a calculation of the magnitude of the cohesive force is provided.
\end{abstract}

\section{INTRODUCTION}

Mycoplasma mobile strain $163 \mathrm{~K}$, which was isolated from the gills of a freshwater fish (Kirchhoff et al., 1983, 1987b; Kirchhoff \& Rosengarten, 1984), is characterized by its gliding motility and its striking cell shape, with a pronounced head-like structure on the forward end (Kirchhoff \& Rosengarten, 1984; Kirchhoff et al., 1984, 1987 b). It is distinguished from the other gliding mycoplasmas, i.e. M. pneumoniae, M. genitalium, M. gallisepticum and M. pulmonis, by the high speed of its movement on inert surfaces (Kirchhoff et al., 1984; Rosengarten \& Kirchhoff, 1987a) as well as on erythrocytes (Fischer et al., 1987), by its ability to transport attached erythrocytes along a glass surface without significant speed reduction (Rosengarten $e t$ al., 1987), and finally by its capability of chemotactic responses to a range of attractants (Kirchhoff et al., 1987a). In a previous paper (Rosengarten \& Kirchhoff, 1987a) we briefly reported that, in contrast to the other gliding mycoplasmas, $M$. mobile is able to form wandering groups ranging from pairs to multicellular configurations in which temporary intercellular associations are prevalent. These data, together with preliminary ultrastructural findings (Kirchhoff $e t$ al., 1987 b), suggested the presence of an extracellular mucus layer mediating the cohesion between the cells. In this paper, the tendency to multicellular behaviour of $M$. mobile is illustrated in more detail, and further evidence for the involvement of an extramembranous mucus layer in this process is presented.

\section{METHODS}

Organism and growth. M. mobile 163K (Kirchhoff \& Rosengarten, 1984; Kirchhoff et al., 1987b) was cultivated as previously described (Fischer et al., 1987; Kirchhoff et al., 1987a). The investigations were performed with the 14th to 22nd medium subculture after isolation.

Preparation for light microscopy. Organisms of $M$. mobile $163 \mathrm{~K}$ were obtained by rinsing agar cultures showing dense growth with liquid culture medium. A $5 \mu \mathrm{I}$ drop of the mycoplasma cell suspension, containing about $10^{8}$ c.f.u. $\mathrm{ml}^{-1}$, was placed on a glass slide, covered with a glass coverslip and sealed with paraffin.

Dark-field microscopy and photomicrography. A Leitz standard photomicroscope equipped with dark-field optics was used. The movements of small groups of coherent cells were recorded photomicrographically by long 
exposures, resulting in motility tracks on the film (Rosengarten \& Kirchhoff, 1987a). Photomicrographs were taken with Kodak Tri-X Pan film (400 ASA) using exposure times of $10-40 \mathrm{~s}$.

Interference microscopy and microcinematography. The interactions between the gliding mycoplasma cells were microcinematographically recorded with an Arri-Techno camera fitted to a Zeiss WL-microscope equipped with Normarski interference optics. Recordings were made on $35 \mathrm{~mm}$ colour film (ECH 5294) using a frequency of 24 frames $\mathrm{s}^{-1}$.

Preparation for scanning and negative-contrast electron microscopy. All methods have been described previously (Kirchhoff et al., 1987b). Briefly, M. mobile cells were grown in liquid medium on Pioloform (Dr Walter Hert Mikrotechnik, München, FRG) coated copper grids and glass coverslips for transmission and scanning electron microscopy, respectively. After $48 \mathrm{~h}$, the attached cells were either negatively stained with ammonium molybdate or fixed in glutaraldehyde, postfixed with osmium tetroxide, dehydrated in ethanol, critical-point dried in liquid carbon dioxide and gold sputter-coated. The negatively stained specimens were examined in a Zeiss EM 10 at 80 $\mathrm{kV}$, and the samples prepared for scanning electron microscopy in a Jeol JSM 35C at $25 \mathrm{kV}$.

Preparation for thin-section electron microscopy. For ultrastructural studies, the mycoplasma cells were grown in liquid medium for $48 \mathrm{~h}$. The pelleting, washing, fixation, dehydration and embedding procedures have been described (Kirchhoff et al., 1987 b). In order to demonstrate a possible extramembranous mucus layer, the cells were fixed in the presence of ruthenium red (Luft, 1971) according to the method described by Springer \& Roth (1973). Thin sections were cut on an LKB 4800 ultramicrotome with glass knives, stained with uranyl acetate followed by lead citrate, and examined in a Zeiss EM 10 at $80 \mathrm{kV}$ (Kirchhoff et al., 1987b).

Calculation of the cell cohesiveness. The cohesion force holding two adjacent cells together in an end-to-end position is equivalent to the force required to separate the two cells from each other. The magnitude of this force corresponds to the twofold value of the previously calculated propulsive force (Rosengarten et al., 1987), which was deduced from the motility-driving energy (Rosengarten \& Kirchhoff, 1987b; Rosengarten et al., 1987) and depends on the medium viscosity, the geometrical cell properties and the gliding velocity (Rosengarten \& Kirchhoff, 1987b).

\section{RESULTS}

\section{Cell cohesion and group motility}

Besides its movement as single cells, M. mobile showed a remarkable degree of cellular interactions during gliding, with a striking tendency towards multicellular groupings. This was observed particularly in dense cell populations, where the cells usually became slower (Rosengarten \& Kirchhoff, 1987a) forming either small groups of two (Fig. 1), three (Fig. 2) or more (Fig. 3) cells aligned in parallel, or long linear chain-like aggregations (Fig. 4). These groups moved as single coherent units on the glass surface, behaving in this respect like the 'swarms' of many gliding bacteria (Reichenbach, 1981, 1984). In the extreme, the multicellular behaviour of $M$. mobile resulted in the translocation of microcolonies. The speed of movement of the smaller wandering groups was comparable to that of singly gliding cells, but the speed decreased with increasing size of the moving aggregate or microcolony. The intercellular interactions appeared to be rather loose, since the cell groupings constantly changed (Fig. 4): new groups formed, and existing groups enlarged, diminished or broke up. This behaviour correlated with the theoretically calculated strength of cohesion between two mycoplasma cells in an end-to-end position before separating and moving away from each other as individuals (Rosengarten \& Kirchhoff, $1987 a$ ) : by assuming a value of $46.05 \times 10^{-15} \mu \mathrm{J} \mathrm{s}^{-1}$ (Rosengarten \& Kirchhoff, $1987 \mathrm{~b}$ ) for the propulsive energy of both dissociating mycoplasma cells, and $3.05 \mu \mathrm{m}$ $\mathrm{s}^{-1}$ for the gliding velocity (Rosengarten \& Kirchhoff, $1987 a, b$ ), the cohesion force holding the two cells together can be calculated to be approximately $3.0 \times 10^{-8} \mu \mathrm{N}$, a value considerably less than the adhesion values calculated for the interaction of this organism with erythrocytes or glass (Rosengarten et al., 1987).

\section{Ruthenium-red-staining surface layer}

The electron microscopic investigations provided strong evidence for the presence of an amorphous-to-floccular extracellular material coating the surface of the cytoplasmic membrane of $M$. mobile (Fig. $5 a$ ). The demonstration of an extramembranous layer surrounding the whole mycoplasma cell could be improved (Fig. $5 b$ ) by the use of an electron-dense osmium-ruthenium red complex which has an affinity for polyanions (Luft, 1971). The negative-contrast and 

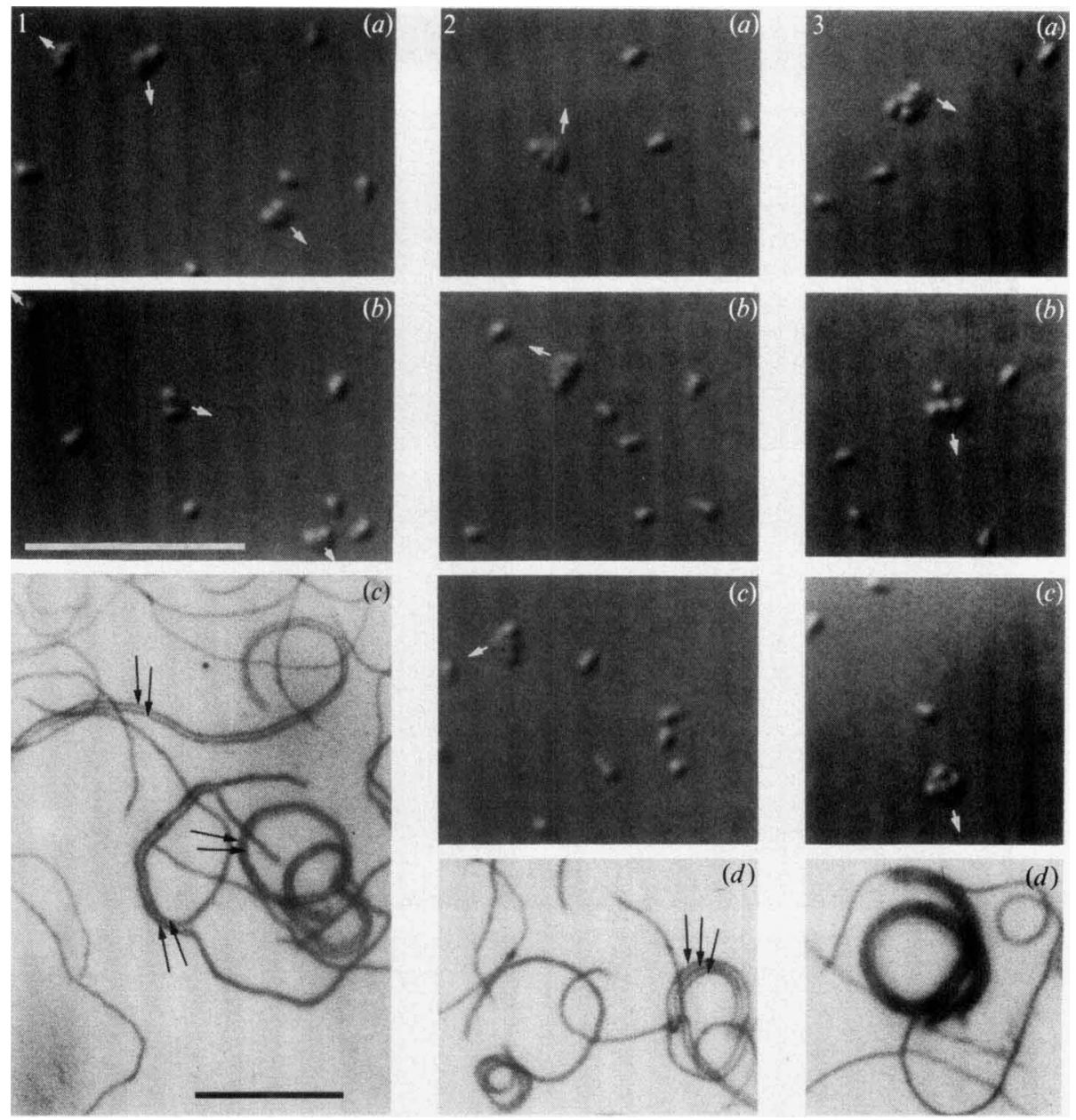

Figs 1, 2 and 3. Photomicrographs of sequential Nomarski interference-contrast microcinematographic frames $(1 a-b, 2 a-c, 3 a-c)$ and negative prints of prolonged-exposure dark-field photomicrographs $(1 c, 2 d, 3 d)$, showing the movements of small wandering groups of $M$. mobile $163 \mathrm{~K}$ consisting of two (Fig. 1), three (Fig. 2) or four (Fig. 3) cells. Arrows indicate the resulting double $(1 c)$ or triple $(2 d)$ motility tracks and they point in the direction of translocation $(1 a-b, 2 a-c, 3 a-c)$. Bars represent $10 \mu \mathrm{m}$.

scanning electron micrographs of adjacent cells in Fig. 5(c) and Fig. 5(d), respectively, show that the extracellular polyanionic material can hold the cells together by bridging the interspace between them.

\section{DISCUSSION}

It has been assumed so far that gliding mycoplasmas move as individual cells only (Radestock \& Bredt, 1977). There are, however, brief notes (Andrewes \& Welch, 1946; Bredt \& Radestock, 1977; Bredt, 1979) describing a kind of multicellular movement for $M$. pulmonis in that occasionally, nonmotile clustered cells were observed to be pulled by a motile cell. The motility studies in this and a preceding paper (Rosengarten \& Kirchhoff, 1987a) show that, in contrast to M. pneumoniae (Radestock \& Bredt, 1977; Bredt, 1979), M. gallisepticum (Erdmann, 1976; Bredt, 1979), M. pulmonis (Andrewes \& Welch, 1946; Bredt \& Radestock, 1977; Bredt, 1979) and M. genitalium (Taylor-Robinson \& Bredt, 1983), M. mobile exhibits two distinct patterns of cell movement, namely single-cell movement and cell-group movement. 

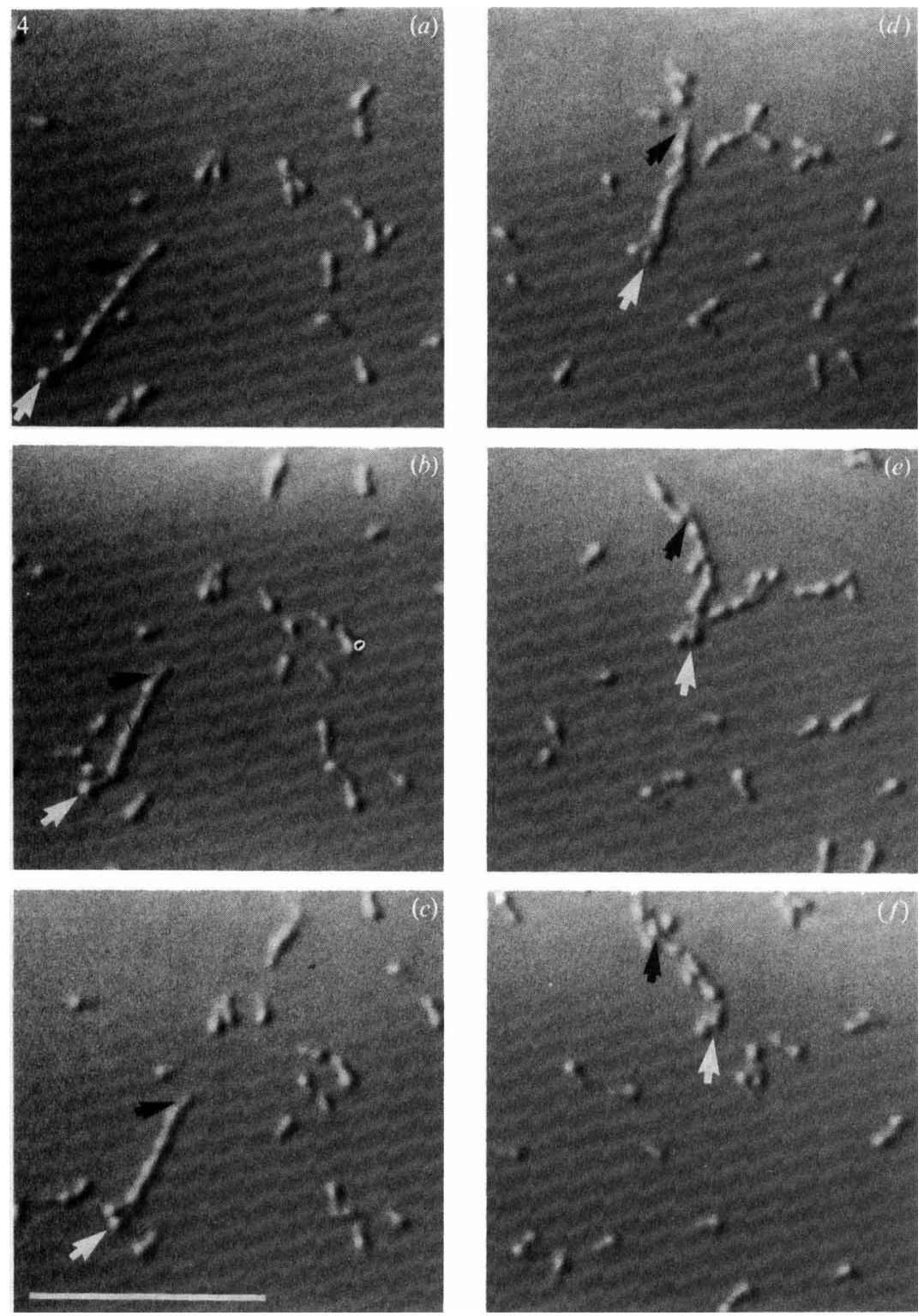

Fig. 4. A sequence of Nomarski interference-contrast microcinematographic pictures, showing the movement of a chain-like cell aggregate of $M$. mobile $163 \mathrm{~K}$. The leading cell within the chain is marked by a black arrow and the terminal cell by a white arrow. Bar represents $10 \mu \mathrm{m}$.

Our investigations confirm previous observations on $M$. mobile ultrastructure (Kirchhoff et $a l ., 1987 b$ ) and gliding motility (Rosengarten \& Kirchhoff, 1987a), namely that $M$. mobile possesses a surface layer of amorphous material external to the cell membrane (Kirchhoff et al., $1987 b$ ) which may play an important role in the observed group motility (Rosengarten \& Kirchhoff, 1987a). We have shown that this extramembranous material can be stained intensively with ruthenium red, which is thought by Luft (1971) to bind most strongly to extracellular polyanions, usually present as acidic mucopolysaccharides in glycoproteins. However, since ruthenium red does not react specifically with any group of chemical compounds, definite conclusions on the chemical nature of the $M$. mobile surface layer cannot be made. 

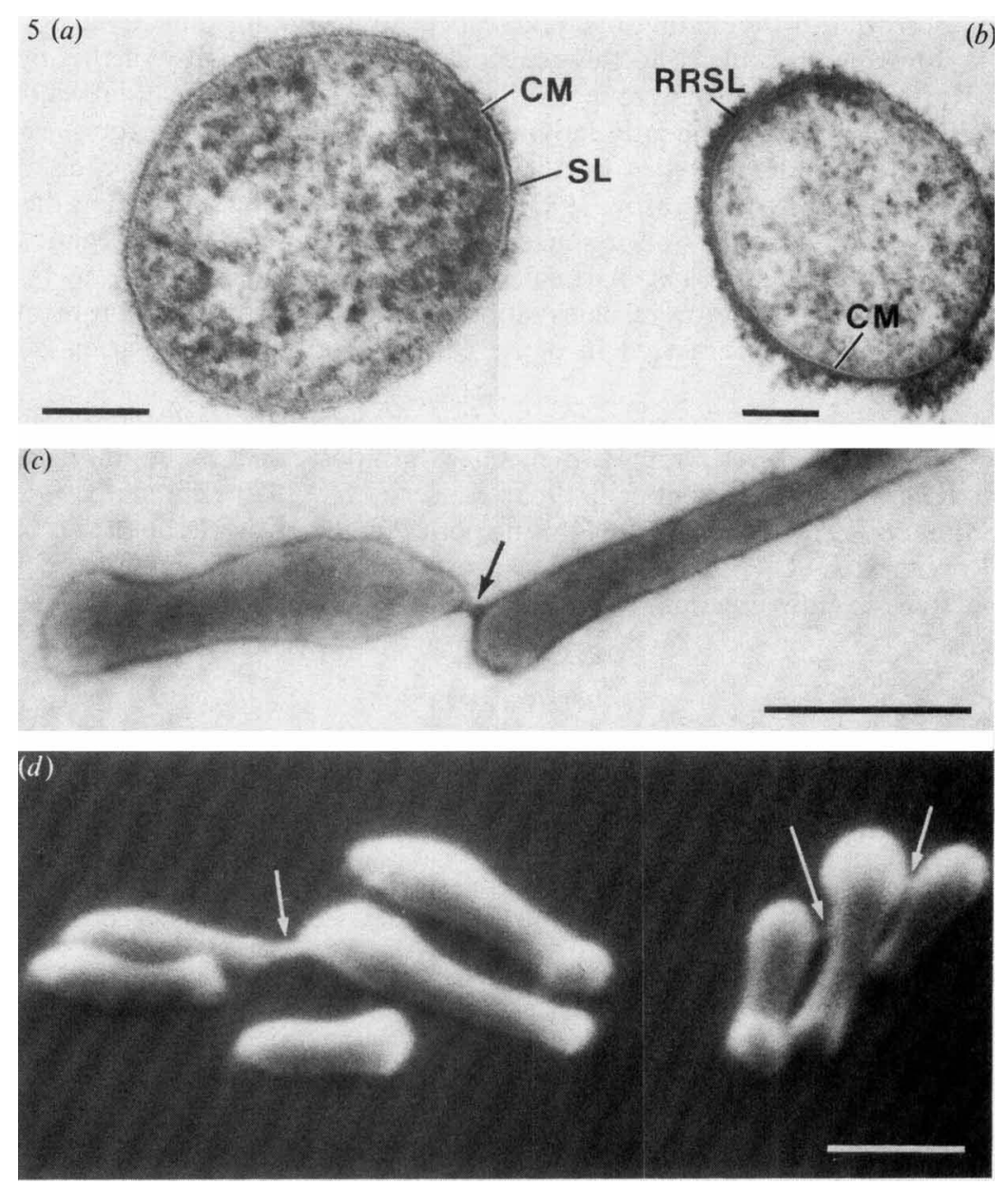

Fig. 5. Transmission $(a, b, c)$ and scanning $(d)$ electron micrographs of both ruthenium-red-untreated $(a)$ and ruthenium-red-treated $(b)$ ultrathin-sectioned $(a, b)$, negatively stained $(c)$ and critical-pointdried $(d)$ cells of $M$. mobile $163 \mathrm{~K}$, showing $(a)$ a diffuse surface layer (SL) of $(b)$ amorphous ruthenium red-staining material (RRSL) outside the cytoplasmic membrane $(\mathrm{CM})$ which appears $(c, d)$ to interconnect adjacent cells by forming thin intercellular bridges (arrows). Bars represent $0 \cdot 1 \mu \mathrm{m}(a, b)$ and $0.5 \mu \mathrm{m}(c, d)$.

The presence of a ruthenium-red-staining surface layer has also been reported for the gliding mycoplasma species $M$. pneumoniae (Wilson \& Collier, 1976) and M. gallisepticum (Ajufo \& Whithear, 1978; Tajima et al., 1982). Wilson \& Collier (1976) suggested that the surface material of $M$. pneumoniae may play a role in its adhesiveness and its gliding motility. Indeed it is not unlikely that the polyanionic surface layer of the gliding mycoplasmas $M$. pneumoniae, $M$. gallisepticum and $M$. mobile has the same function as the extracellular slime of the gliding bacteria, namely (1) mediating attachment of the cell to the substratum (Marshall et al., 1971; Marshall \& Cruickshank, 1973) and (2) allowing and facilitating the movement on that substratum (Costerton $e t$ al., 1961) by reducing the friction between the contacted surfaces. These properties are characteristic of a temporary adhesive (Humphrey et al., 1979). Furthermore, the electron microscopic investigations of adjacent cells of $M$. mobile in this study have shown that the surface layer of this organism may also account for its cell cohesiveness and its ability to form multicellular wandering groups.

The tendency of the $M$. mobile cells to glide in groups with their long axes parallel and to remain in contact with adjacent cells resembles at least in some aspects the swarming 
phenomenon observed in the gliding bacteria, especially in the myxobacteria (Reichenbach, 1981, 1984). However, in contrast to the genetically controlled motility of the myxobacteria (Hodgin \& Kaiser, $1979 a, b$ ), the group motility of $M$. mobile obviously arises by transient association of primarily independently moving cells, or by cell multiplication leading to the formation of wandering microcolonies. Furthermore, in contrast to the organized social motility of the myxobacteria (Kaiser \& Crosby, 1983), there is no coordination among the associated mycoplasma cells: they glide in a disorganized nonsocial manner. The aggregation of the $M$. mobile cells into wandering groups, particularly into long chains, appears to be related to physiological stress, such as nutrient deprivation, as indicated by reduction of motility, the phenomenon being most pronounced in dense cell populations (Rosengarten \& Kirchhoff, $1987 a$ ).

The kind of interactions between cells that are necessary for producing a multicellular condition could have evolved from two mechanisms possessed by solitary cells, namely chemotaxis (Kühlwein \& Reichenbach, 1965; Kaiser et al., 1979; Burchard, 1984) and cell cohesion (Shimkets, 1986). M. mobile, exhibiting both chemotactic (Kirchhoff et al., 1987a) and cohesive (Rosengarten \& Kirchhoff, 1987a) properties, may represent one of the earliest evolutionary steps in this direction.

\section{REFERENCES}

AJUFo, J. C. \& WhITHEAR, K. G. (1978). Evidence for a ruthenium red-staining extracellular layer as the haemagglutinin of the WVU 1853 strain of $\mathrm{Myco-}$ plasma synoviae. Australian Veterinary Research 54, 502-504.

ANDReWES, C. H. \& Welch, F. V. (1946). A motile organism of the pleuropneumonia group. Journal of Pathology and Bacteriology 58, 578-580.

BREDT, W. (1979). Motility. In The Mycoplasmas, vol. I, pp. 141-155. Edited by M. F. Barile \& S. Razin. New York, San Francisco \& London: Academic Press.

BREDT, W. \& RADESTOCK, U. (1977). Gliding motility of Mycoplasma pulmonis. Journal of Bacteriology 130 , 937-938.

BURCHARD, R. P. (1984). Gliding motility and taxes. In Myxobacteria : Development and Cell Interactions, $\mathrm{pp}$. 139-161. Edited by E. Rosenberg. New York: Springer-Verlag.

Costerton, J. W. F., Murray, R. G. E. \& Robinow, C. F. (1961). Observations on the motility and structure of Vitreoscilla. Canadian Journal of Microbiology 7, 329-339.

ERDMANN, T. (1976). Morphologie, Vermehrung und Beweglichkeit von Mycoplasma gallisepticum. MD thesis, Johannes Gutenberg Universität, Mainz, FRG.

Fischer, M., KirchHoff, H., Rosengarten, R., KerleN, G. \& SeACK, K.-H. (1987). Gliding movement of Mycoplasma sp. nov. strain 163K on erythrocytes. FEMS Microbiology Letters 40, 321324.

Hodgin, J. \& Kaiser, D. (1979a). Genetics of gliding motility in Myxococcus xanthus (Myxobacterales) genes controlling movements of single cells. Molecular and General Genetics 171, 167-176.

HODGIN, J. \& KAISER, D. (1979b). Genetics of gliding motility in Myxococcus xanthus (Myxobacterales): two gene systems control movement. Molecular and General Genetics 171, 177-191.

Humphrey, B. A., Dickson, M. R. \& Marshall, K. C (1979). Physicochemical and in situ observations on the adhesion of gliding bacteria to surfaces. Archives of Microbiology 120, 231-238.

KAISER, D. \& Crosby, C. (1983). Cell movement and its coordination in swarms of Myxococcus xanthus. Cell Motility and the Cytoskeleton 3, 227-245.

Kaiser, D., Manoll, C. \& Dworkin, M. (1979). Myxobacteria: cell interactions, genetics and development. Annual Review of Microbiology 33, 595-639.

KIRCHHOFF, H. \& ROSENGARTEN, R. (1984). Isolation of a motile mycoplasma from fish. Journal of General Microbiology 130, 2439-2445.

KiRCHHOFf, H., RosengaRten, R. \& Chercheletzi, C. (1983). Isolation of mycoplasmas from a tench (Tinca tinca L.). Yale Journal of Biology and Medicine 56, 841-842.

KIRChHOFF, H., Rosengarten, R., Lotz, W., Fischer, M. \& LopatTa, D. (1984). Flask-shaped mycoplasmas: properties and pathogenicity for man and animals. Israel Journal of Medical Sciences 20, 848-853.

KirchHOFF, H., Boldt, U., Rosengarten, R. \& Klein-StruCKmeIeR, A. (1987a). Chemotactic response of a gliding mycoplasma. Current Microbiology 15, 57-60.

KirchHOFF, H., Beyene, P., Fischer, M., Flossdorf, J., Heitmann, J., Khattab, B. Lopatta, D., Rosengarten, R., Seidel, G. \& Yousef, C. (1987b). Mycoplasma mobile sp. nov., a new species from fish. International Journal of Systematic Bacteriology 37, 192-197.

KÜHLWEIN, H. \& ReICHENBACH, H. (1965). Schwarmentwicklung und Morphogenese bei Myxobakterien: Archangium-Myxococcus-Chondrococcus-Chondromyces. Scientific film C893. Göttingen: Institut für den Wissenschaftlichen Film.

LUFT, J. H. (1971). Ruthenium red and violet. I. Chemistry, purification, methods of use for electron microscopy and mechanism of action. Anatomical Record 171, 347-368.

Marshall, K. C. \& Cruickshank, R. H. (1973). Cell surface hydrophobicity and the orientation of cer- 
tain bacteria at interfaces. Archiv für Mikrobiologie 91, 29-40.

Marshall, K. C., Stout, R. \& Mitchell, R. (1971). Mechanism of the initial events in the sorption of marine bacteria to surfaces. Journal of General Microbiology 68, 337-348.

RADESTOCK, U. \& BREDT, W. (1977). Motility of Mycoplasma pneumoniae. Journal of Bacteriology 129, 1495-150I.

REICHENBACH, H. (1981). Taxonomy of the gliding bacteria. Annual Review of Microbiology 35, 339-364.

REICHENBACH, H. (1984). Myxobacteria: a most peculiar group of social prokaryotes. In Myxobacteria : Development and Cell Interactions, pp. 1-50. Edited by E. Rosenberg. New York: Springer-Verlag.

ROSENGARTEN, R. \& KIRCHHOFF, H. (1987a). Gliding motility of Mycoplasma sp. nov. strain 163K. Journal of Bacteriology 169, 1891-1898.

RosengaRTEN, R. \& KirchHOFF, H. (1987b). Energetic aspects of the gliding motility of mycoplasmas. Current Microbiology (in the Press).
Rosengarten, R., Fischer, M., KIRChHoff, H., Kerlen, G. \& SEACx, K.-H. (1987). Transport of erythrocytes by gliding cells of Mycoplasma mobile 163K. Current Microbiology (in the Press).

SHIMKETS, L. J. (1986). Correlation of energy-dependent cell cohesion with social motility in Myxococcus xanthus. Journal of Bacteriology 166, 837-841.

SPRINGER, E. L. \& Roth, I. L. (1973). The ultrastructure of the capsules of Diplococcus pneumoniae and Klebsiella pneumoniae stained with ruthenium red. Journal of General Microbiology 74, 21-31.

Tajima, M., Yagihashi, T. \& Miki, Y. (1982). Capsular material of Mycoplasma gallisepticum and its possible relevance to the pathogenic process. Infection and Immunity 36, 803-833.

TAYLOR-ROBINSON, D. \& BREDT, W. (1983). Motility of Mycoplasma strain G 37. Yale Journal of Biology and Medicine 56, 910-911.

Wilson, M. H. \& Collier, A. M. (1976). Ultrastructural study of Mycoplasma pneumoniae in organ culture. Journal of Bacteriology 125, 332-339. 